\title{
PENGARUH KONFORMITAS TEMAN SEBAYA, MOTIVASI DAN MINAT KARIR TERHADAP PEMILIHAN PROGRAM STUDI AKUNTANSI DI PERGURUAN TINGGI
}

\author{
Istiqomah \\ e-mail: istiPPIindonesia@gmail.com \\ Lilik Sri Hariani \\ e-mail: liliksrihariani@unikama.ac.id \\ Affan Afian \\ e-mail:affanafian@unikama.ac.id
}

\begin{abstract}
(Program Studi Pendidikan Ekonomi, Fakultas Ekonomika dan Bisnis, Universitas Kanjuruhan, Malang)
\end{abstract}
\begin{abstract}
Peer conformity, motivation, and career interests influence the selection of Accounting study programs in Higher Education. Peer conformity is common in the social environment of students, highly motivated, and career interests make students interested in choosing Accounting study programs. The purpose of this study was to determine the effect of peer conformity, motivation, and career interests on the selection of accounting study programs in tertiary institutions. The research method uses quantitative methods using multiple linear regression. The population in this study were all students of the Unikama Accounting study program totaling 665 students with a research sample of 100 students. The sampling technique uses stratified random sampling method. analyzing data with the help of SPSS application version 22.00 for windows. Based on the results of calculations, it is known that there is an influence of peer conformity, motivation, and career interests simultaneously on the selection of accounting study programs in Higher Education both partially and simultaneously. Choosing a study program should be chosen in accordance with the foreseeable consideration in accordance with interests, talents, and abilities.
\end{abstract}

Keywords : peer conformity, motivation, career interests, selection of accounting study programs.

\begin{abstract}
Abstrak: Konformitas teman sebaya, motivasi, dan minat karir berpengaruh terhadap pemilihan program studi Akuntansi di Perguruan Tinggi. Konformitas teman sebaya umum terjadi di lingkungan sosial mahasiswa, motivasi yang tinggi, dan minat karir maka membuat mahasiswa tertarik untuk memilih prodi Akuntansi. Tujuan penelitian ini untuk mengetahui pengaruh konformitas teman sebaya, motivasi, dan minat karir terhadap pemilihan program studi akuntansi di Perguruan Tinggi. Metode penelitian menggunakan metode kuantitatif dengan menggunakan regresi linier berganda. Populasi dalam penelitian ini adalah seluruh mahasiswa program studi Akuntansi Unikama yang berjumlah 665 mahasiswa dengan sampel penelitian yang berjumlah 100 mahasiswa. Teknik pengambilan sampel menggunakan metode stratified random sampling. penganalisisan data dengan bantuan aplikasi SPSS versi 22.00 for windows. Berdasarkan hasil perhitungan, diketahui bahwa terdapat pengaruh konformitas teman sebaya, motivasi, dan minat karir secara simultan terhadap pemilihan program studi akuntansi di Perguruan Tinggi baik secara parsial maupun simultan. Memilih program studi hendaklah dipilih sesuai dengan pertimbangan yang sudah diperkirakan sebelumnya yang sesuai dengan minat, bakat, dan kemampuan.
\end{abstract}

Kata kunci : konformitas teman sebaya, motivasi, minat karir, pemilihan program studi akuntansi 


\section{PENDAHULUAN}

Pendidikan menjadi salah satu faktor yang paling penting untuk memajukan dan mencerdaskan bangsa. Hal tersebut juga tertuang dalam pembukaan UUD 1945 dan termuat dalam UU No.22 tahun 2003. Lembaga perguruan tinggi didirikan untuk mencetak sumber daya manusia (SDM) yang berkualitas tinggi dan mampu bersaing dan dapat mengikuti perkembangan zaman serta tuntutan kebutuhan yang semakin banyak. Selain itu, lembaga perguruan tinggi juga menjadi salah satu tujuan masyarakat untuk meningkatkan pendidikan yang berpokok pada satu bidang konsentrasi ilmu yang dibutuhkan untuk bisa memasuki suatu dunia kerja. Melalui pendidikan di perguruan tinggi seseorang berusaha untuk mengembangkan dirinya agar memperoleh pengetahuan mengenai konsep, prinsip, kreativitas, keterampilan serta tanggung jawab (Iramawati, 2008: 69).

Perguruan tinggi swasta maupun negeri berlomba untuk menyediakan berbagai program studi. Berdasarkan hasil survei nasional oleh majalah Tempo tahun 2016 dengan hasil 12 fakultas yang menjadi incaran dan favorit calon mahasiswa. Hasil survei menunjukkan bahwa peringkat 2 besar di tempati oleh Fakultas Ekonomika dengan program studi Akuntansi. Salah satu perguruan tinggi swasta yang berbasis kependidikan dan murni adalah Universitas Kajuruhan Malang (Unikama). Unikama sendiri memiliki 5 fakultas yang terdiri dari Fakultas Ekonomika dan Bisnis, Fakultas Ilmu Pendidikan, Fakultas Sains dan Teknologi, Fakultas Peternakan, dan Fakultas Bahasa dan Sastra. Salah satu program studi yang memiliki peminat paling banyak adalah program studi Akuntansi di Fakultas Ekonomika dan Bisnis. Peminat program studi tersebut cenderung mengalami peningkatan mengingat ilmu Akuntansi sendiri saat ini banyak dibutuhkan di segala bidang. Tidak hanya calon mahasiswa dari SMK saja yang berminat, namun calon mahasiswa dari SMA juga banyak yang meminati.

Kegiatan keuangan tidak pernah terlepas dari kegiatan sehari-hari manusia. Semua orang membutuhkan cara agar keuangannya dapat diatur secara bijak. Tidak hanya orang secara pribadi, tetapi sebuah perusahaan juga membutuhkan sistem agar keuangan perusahaannya bisa dikontrol dengan tepat. Secara tidak langsung akuntansi sangat dekat dengan kehidupan sehari-hari. Sebelum mengambil keputusan memilih prodi, calon mahasiswa mungkin membuat penilaian mengenai kelebihan dan kekurangan dari prodi yang akan dipilihnya. Hal tersebut yang berhubungan dengan lingkungan sosial, minat, keterampilan, dan lain sebagainya. Kemudian memutuskan untuk mengambil program studi yang sesuai dengan kriteria yang sudah dipertimbangkan sebelumnya. Pemilihan prodi ini dilakukan oleh calon mahasiswa yang umumnya berusia 15-19 tahun. Usia tersebut digolongkan oleh Santrok (2014) ke dalam usia remaja, dimana dalam usia ini remaja masih mengalami banyak perkembangan.

Peniruan pada seorang remaja sangat lumrah dan umum terjadi. Hal tersebut berdampak pada sikap, perilaku bahkan pengambilan keputusan. Myers (2012: 8) mengatakan bahwa adanya perubahan perilaku dan kepercayaan yang dipengaruhi oleh tekanan kelompok yang dirasakan secara nyata hanya sebatas imajinasi disebut konformitas. Konformitas pada remaja bisa dirasakan dan dialami secara nyata maupun hanya sebatas imajinasi yang diakibatkan oleh tekanan pada kelompok teman sebaya. Umumnya sikap konformitas ini dilakukan akibat karena remaja atau mahasiswa kurang melihat lebih jauh informasi yang mereka peroleh dan juga karena remaja banyak waktu yang dihabiskan bersama teman-teman mereka. Selain itu juga adanya tekanan agar diterima oleh kelompok teman sebayanya, hal tersebut berdampak pada tindakan dan perilaku mereka yang disesuaikan dengan kelompok teman sebayanya. Seperti memilih prodi Akuntansi di perguruan tinggi.

Motivasi atau dorongan dari diri sendiri maupun orang lain juga diduga mempengaruhi pemilihan prodi di perguruan tinggi oleh mahasiswa. Motivasi merupakan perubahan kekuatan dalam diri seseorang yang dapat dirasakan dari timbulnya perasaan atau reaksi untuk memperoleh 
tujuan tersebut (Djamarah,2008: 22). Mahasiswa yang mempunyai dorongan yang bermula dari perasaan dari dalam dirinya untuk bisa meraih tujuan yang diinginkannya supaya bisa membuktikan bahwa apa yang dilakukannya sudah benar seperti memilih prodi Akuntansi. Motivasi yang berdasar dari luar diri individu seperti adanya harapan dari orang terdekat yang mendorong individu untuk memilih sesuai dengan keinginan orang lain, biasanya mereka adalah keluarga. Karena interaksi yang dilakukan mahasiswa dengan keluarga sangat intens menimbulkan kepercayaan yang erat antara mahasiswa dengan keluarganya.

Setiap mahasiswa umumnya memiliki kecenderungan atau perhatian utama pada suatu profesi. Biasanya hal tersebut dirasakan apabila mahasiswa memiliki minat yang amat kuat pada jenis profesi tertentu. Banyaknya profesi yang berkembang membuat mahasiswa mampu melihat profesi mana yang ke depannya akan mereka tekuni. Informasi mengenai suatu profesi bisa mereka peroleh dari berbagai sumber, seperti keluarga, saudara, guru, komunitas, dan lain sebaginya. Semakin berkembangnya zaman, berkembang pula kebutuhan manusia. Seperti pada bidang keuangan dan akuntansi, ada berbagai bidang yang ditawarkan seperti akuntan perusahaan (internal), akuntan publik (eksternal), guru atau pendidik, konsultan keuangan.

\section{TINJAUAN PUSTAKA}

Pemilihan prodi yang diambil mahasiswa berdasarkan pertimbangan-pertimbangan yang matang. Menurut Geldard (2011: 187) seorang remaja mengembangkan kemampuan untuk berpikir secara logis untuk membuat penilaian dan keputusan bagi diri mereka sendiri. Pertimbangan sebelum memutuskan sesuatu juga didasarkan atas pertimbangan yang bermula dari motivasi, desakan dari luar maupun dari lingkungan. Pengambilan keputusan menurut Salulu (2008: 232) merupakan keadaan akhir dari suatu proses yang lebih dinamis. Sebelum memutuskan untuk memilih program studi akuntansi, mahasiswa dihadapkan pada penilaian dalam pengambilan keputusan.

Penilaian pengambilan keputusan pendidikan di perguruan tinggi menurut Rumono (2014), mencakup penilaian; 1) pandangan mengenai program studi, 2) prospek yang diperoleh, dan 3) informasi yang mendukung. Pandangan mengenai program studi berarti ketika individu memperhatikan dengan menggunakan pertimbangan yang diterima dengan minat, keyakinan, dan harapan. Program studi menjadi prodi yang dipilih mahasiswa, yang sebelumnya telah mempertimbangkan beberapa kemungkinan seperti plus minus program studi tersebut. Prospek yang diperoleh merupakan kemungkinan-kemungkinan yang nantinya bisa diperoleh dalam suatu proses, kemungkinan tersebut bisa diperoleh sebelum maupun sesudah proses itu berakhir. Informasi yang mendukung berarti adanya penyampaian pemberitahuan atau kabar berita mengenai sesuatu.

Informasi yang didapatkan dari mana saja seperti lingkungan masyarakat, teman, keluarga, maupun media sosial. Informasi yang diterima dapat menjadi pertimbangan untuk mengambil suatu keputusan. Dalam interaksi sosial yang di alami mahasiswa, biasanya dalam sebuah kelompok terjadi konformitas. Myers (2012: 8) mengatakan bahwa adanya perubahan perilaku dan kepercayaan (belief) yang timbul akibat dari kelompok yang terdapat tekanan, hal itu rasakan oleh individu secara nyata ataupun hanya berupa imajinasi. Konformitas ini terjadi saat mahasiswa mencermin tingkah laku maupun sikap orang lain karena timbul tekanan yang kuat ketika masa remaja (Santrock, 2014: 230). Geldard (2011: 193) selama masa remaja, pembentukan kelompok teman sebaya berdasarkan 
konteks perkembangan adalah normal. Kecenderungan tersebut sudah dimulai sejak kanak-kanak. Adanya konformitas ini berdampak pula pada individu untuk mengambil keputusan.

Aspek konformitas teman sebaya (Maklufah:2013) ditandai dengan 3 hal berikut; 1) Kekompakan, tiap anggota harus memiliki pengetahuan mengenai kelompoknya, seperti aktivitas dan kebiasaan. Dengan mengetahui hal tersebut individu dengan mudah membaur dan menepatkan diri dengan kelompoknya. 2) Kesepakatan, kesepakatan berasal dari kepercayaan antar anggotanya, sumbang saran atau pendapat antar anggotanya, serta menyamakan persepsi. 3) Ketaatan. konformitas teman sebaya sebenarnya menuntut adanya tekanan dalam kelompok pada remah yang membuat mereka rela untuk melakukan suatu hal atas kesepakatan kelompoknya, meskipun hal tersebut sebenarnya tidak sepenuhnya mereka inginkan.

Asal motivasi bersumber dari kata kerja latin movere (menggerakkan). Menurut Shunck (2012: 7) motivasi merupakan proses dipertahankannya aktivitas yang diarahkan pada pencapaian tujuan. Motivasi ada 2 yaitu intrinsik dan ekstrinsik. a) Motivasi intrinsik ialah dorongan yang muncul dari dalam diri individu sendiri. Hal tersebut timbul tanpa desakan dari orang luar, tetapi muncul atas dasar kesediaan diri sendiri. Faktor yang mengakibatkan motivasi intrinsik (Aini:2013) antara lain; kebutuhan, keinginan, kondisi, kesenangan, kerja dam, dan dorongan. b)Motivasi ekstrinsik merupakan motivasi yang berawal dari luar diri individu. Motivasi ini muncul akibat pengaruh karena ajakan, suruhan atau paksaan dari orang lain sehingga seseorang mau untuk melakukan sesuatu. Faktor yang mendorong motivasi ekstrinsik (Aini:2013) antara lain; imbalan, harapan, kondisi lingkungan sosial, kondisi lingkungan non-sosial.

Minat adalah gejala daya tarik yang timbul akibat adanya faktor dari luar dan dalam diri individu (Dalyono, 2005: 167). Sedangkan menurut Djaali (2008: 86) minat berkaitan dengan suatu perilaku yang mampu mendorong seorang untuk berhadapan dan berhubungan dengan orang, benda, kegiatan maupun pengalaman yang didapatkan melalui kegiatan itu. Kesimpulannya minat merupakan kesediaan atau kecenderungan terhadap suatu yang menarik perhatiannya sehingga menimbulkan perasaan suka terhadap sesuatu. Di antaranya yaitu tertarik pada jenis suatu pekerjaan. Dengan pekerjaan ini timbul keinginan untuk lebih mengembangkan lagi keahlian yang dikuasai agar bisa menempati suatu jabatan yang diharapkan oleh individu.

Karir menurut (Simamora, 2001: 505) adalah kegiatan yang berpautan antara pekerjaan dan tekad seseorang selama waktu bekerja orang tersebut. untuk menentukan minat karir langkahlangkah dalam penentuannya menurut Zulaikha (2014) adalah sebegai berikut: Sikap terhadap karir,sSikap terhadap karier merupakan kecondongan untuk bertindak, berperilaku, dan persetujuan akan sesuatu. Hal tersebut berarti kecenderungan individu pada karir tertentu. Keterampilan pembuatan keputusan karir, keterampilan tersebut mengacu kepada; a) penggunaan pengetahuan dan b) penggunaan pandangan dalam memutuskan keputusan karir. Informasi dunia kerja, informasi dunia kerja ialah segala sesuatu yang berpautan dengan dunia kerja, yang semula orang tidak tahu menjadi tahu mengenai dunia kerja tersebut. ada 2 hal mencakup informasi dunia kerja, yaitu; a) informasi tentang pekerjaan tertentu, dan b) informasi tentang orang lain dalam pekerjaan tertentu.

Kajian Empiris yang digunakan dalam penelitian ini adalah; 1) Penelitian oleh Ester dan Blannie (2013). Tentang faktor-faktor yang mempengaruhi remaja perkotaan AS memilih jurusan Pertanian. 2) Penelitian oleh Erlita Risnawati dan Soni Agus Irwandi (2012). Tentang analisis faktor atas pengambilan keputusan mahasiswa untuk memilih jurusan akuntansi di STIE Perbanas 
Surabaya. 3) Penelitian oleh Rina Isnaeni (2015). Tentang pengaruh motivasi, kelompok referensi, dan biaya pendidikan terhadap keputusan mahasiswa dalam menempuh pendidikan pada Jurusan Pendidikan Ekonomi Fakultas Ekonomika Universitas Negeri Yogyakarta. 4) Penelitian oleh Dwi Pratiwi Priastuti (2014). Tentang hubungan konformitas teman sebaya dengan intensi pemilihan jurusan kuliah pada siswa kelas XI di SMA Negeri 3 Malang. 5) Penelitian oleh Anna Rufaidan (2015). Tentang pengaruh intelegensi dan minat siswa terhadap putusan pemilihan jurusan.

Konformitas menurut Santrock (2014) terjadi ketika individu meniru sikap atau tingkah laku orang lain karena adanya tekanan oleh orang lain yang dirasakan yang sangat kuat saat remaja. Pengaruh saat masa perkembangan remaja sangat kuat, terutama saat remaja, individu yang mengalami konformitas cenderung untuk meniru apa yang dilakukan atau apa yang dipilih oleh teman-temannya, termasuk dalam memilih program studi akuntansi di perguruan tinggi. Mereka meniru hal tersebut agar bisa diterima oleh kelompoknya.

Motivasi merupakan proses dipertahankannya aktivitas yang diarahkan pada pencapaian tujuan (Schunk:2012). Motivasi selain berasal dari dalam diri sendiri atau biasa disebut dengan intrinsik juga berasal dari luar diri individu atau ekstrinsik. Dorongan yang ada memberikan pengaruh terhadap pengambilan keputusan mahasiswa. Dengan memiliki motivasi, mahasiswa terdorong untuk memilih program studi akuntansi.

Minat adalah gejala psikologis yang timbul akibat adanya faktor daya tarik dari luar dan dalam diri individu (Dalyono:2005). Minat tersebut muncul akibat ketertarikan mahasiswa dalam sesuatu, dalam penelitian ini adalah ketertarikan dalam suatu profesi. Dengan profesi tersebut memunculkan harapan agar bisa mengembangkan kemampuannya saat bekerja nantinya dan bisa menempati karir yang diimpikan. Karir menurut Simamora (2001) adalah aktivitas yang berkaitan dengan pekerjaan. Mahasiswa yang memiliki minat karir dalam bidang akuntansi mendorong mahasiswa untuk memilik program studi akuntansi.

\section{METODE}

Penelitian ini menggunakan pendekatan kuantitatif dengan jenis penelitian ext-post-facto, karena penelitian ini menggunakan variabel yang telah terjadi dan tidak perlu ada perlakuan khusus terhadap variabel yang diteliti. Populasi dalam penelitian ini adalah seluruh mahasiswa program studi Akuntansi Unikama sebayak 665 mahasiswa. Pengambilan sampel menggunakan stratified random sampling karena populasi memiliki sampel yang heterogen dan berstrata secara proporsional. Dan penentuan jumlah sampel adalah sebanyak $10 \%$ dari masing-masing angkatan yang diperoleh jumlah sebayak 100 responden. Instrumen penelitian ini menggunakan angket atau kuesioner. Dimana setiap butir soal menggunakan skala likert.

\section{HASIL DAN PEMBAHASAN}

Pada penelitian ini diperoleh 100 responden yang terdiri dari 26 responden laki-laki dan 74 responden perempuan. Dari 100 responden yang diberikan angket dengan menggunakan skala likert, kemudian data yang diperoleh diolah dengan menggunakan perhitungan menggunakan bantuan SPSS versi 22.00 for windows. Pengelolaan data dilakukan dengan menggunakan statistik dan model regresi linier berganda. Menjawab hipotesis yang sudah disebutkan, dapat diuji dengan salah satunya menggunakan uji F. Berikut adalah pengaruh secara simultan (bersama-sama) antara seluruh variabel bebas dengan variabel terikat. Adapun hasilnya dapat ditujukkan dengan Tabel. 2. 
Tabel 2

Hasil Uji F (Uji secara simultan)

\begin{tabular}{|rr|r|r|r|r|r|}
\hline \multicolumn{1}{|c|}{ Model } & $\begin{array}{r}\text { Sum of } \\
\text { Squares }\end{array}$ & Dr & $\begin{array}{r}\text { Mean } \\
\text { Square }\end{array}$ & F & Sig. \\
\hline 1 & Regression & 934,954 & 3 & 311,651 & 39,364 &, 000 \\
& & & & & \\
& Residual & 760,046 & 96 & 7,917 & & \\
& & & & & \\
& & & & & \\
\hline
\end{tabular}

Sumber: Data diolah 2017

Hasil uji F pada tabel 4 dipeoleh Fhitung sebesar 39,364 dengan tingkat signifikan 0,000. Variabel konformitas teman sebaya (X1), motivasi (X2), dan minat karir (X3) secara bersama-sama atau simultan mempengaruhi pemilihan program studi Akuntansi di Perguruan Tinggi ( $Y$ ) karena tingkat signifikan dibawa 0,05.

Ketika mahasiswa melakukan peniruan akibat dari tekanan yang dilakukan oleh kelompok/sahabat, hal ini bisa mendorong dan menggerakkan mahasiswa untuk memilih program studi Akuntansi. Selain dari dalam diri sendiri, motivasi juga bisa timbul karena ada orang lain yang memberikan dorongan seperti keluarga. Keluarga bisa memberikan gambaran dan informasi mengenai pekerjaan dalam bidang Akuntansi. Informasi yang diperoleh mahasiswa ini bisa menimbulkan kecenderungan mahasiswa pada profesi bidang Akuntansi atau minat karir. Seperti ada anggota keluarga yang bekerja dalam bidang Akuntansi dan anggota keluarga ini memberikan informasi bahwa peluang kerja bidang Akuntansi di perusahaan masih sangat terbuka, dan jenis pekerjaan bidang Akuntansi juga beragam seperti Akuntan publik, konsultan pajak, akuntan pemerintah, dan lain sebagainya. Selain itu, konformitas teman sebaya juga bisa menimbulkan minat karir, Karena sebagian besar kelompok/sahabatnya menyukai akuntansi dan sering belajar akuntansi bersama maka mereka membuat kesepakatan untuk memilih program studi Akuntansi dengan harapan kelompoknya agar ketika nanti lulus dari Perguruan Tinggi mereka bisa sama-sama bekerja dalam bidang Akuntansi.

Melihat pengaruh secara parsial atau pengaruh antara masing-masing variabel bebas terhadap variabel dependen dapat menggunakan Uji t. Hasil uji t dapat ditunjukkan pada Tabel 3.

Tabel 3

Hasil Uji t (Uji secara parsial)

\begin{tabular}{|l|l|r|r|l|}
\hline \multicolumn{1}{|l|}{ Model } & \multicolumn{1}{c|}{ T } & Sig. & Keterangan \\
\hline & (Constant) & 3,321 &, 001 & \\
& konformitas_teman_sebaya & $-4,062$ &, 000 & Signifikan \\
& Motivasi & 9,928 &, 000 & Signifikan \\
& minat_karir & 2,521 &, 013 & Signifikan \\
\hline
\end{tabular}

Pada tabel 3 nilai t-hitung variabel konformitas teman sebaya (X1) sebesar -4,062 dengan tingkat signifikan sebesar 0,000. Maka konformitas teman sebaya (X1) berpengaruh terhadap pemilihan program studi Akuntansi (Y) karena nilai signifikannya di bawah dari 0,05. Nilai t-hitung variabel motivasi (X2) sebesar 9,928 dengan tingkat signifikan sebesar 0,000. Karena nilai signifikan di 
bawah 0,05 maka motivasi (X2) berpengaruh terhadap pemilihan program studi Akuntansi (Y). Dan nilai t-hitung variabel minat karir (X3) sebesar 2,521 dengan tingkat signifikan sebesar 0,013 maka minat karir (X3) berpengaruh terhadap pemilihan program studi Akuntansi (Y) karena nilai signifikan di bawah 0,05 .

Pengaruh negatif pada konformitas teman sebaya tersebut bisa terjadi karena sebagian mahasiswa prodi Akuntansi Unikama mendapat penekanan dan paksaan dari teman dekatnya. Karena merasa tertekan dan tidak mendapat kesempatan untuk mengambil keputusan secara mandiri sedangkan teman dekat pada saat sekolah banyak yang memilih prodi selain Akuntansi, maka saat masih sekolah mereka memutuskan untuk memilih prodi akuntansi di Unikama karena mereka menganggap prodi akuntansi merupakan hal yang favoritkan dan dicita-citakan sejak awal . Hal tersebut juga membuktikan teori Santrock (2014) di mana disebutkan bahwa konformitas terjadi ketika individu meniru sikap atau tingkah laku orang lain karena tekanan yang diberikan sangat kuat. Nalarnya adalah tekanan yang diberikan orang lain termasuk dalam keadaan pemaksaan dan bisa jadi hal tersebut bukan berasal dari keinginan dalam hatinya. Penelitian ini menunjukkan bahwa mahasiswa Program Studi Akuntansi Unikama mengalami sikap konformitas cukup rendah. Jadi, dengan konformitas yang rendah atau tekanan yang diberikan teman dekatnya saat masih sekolah maka bisa menaikkan minat mahasiswa untuk memilih program studi Akuntansi di Unikama.

Motivasi yang mampu mempengaruhi berasal dari dalam diri dan luar diri mahasiswa. Biasa disebut dengan motivasi intrinsik dan ekstrinsik. Mahasiswa program studi Akuntansi Unikama memiliki motivasi yang tinggi untuk memilih Akuntansi sebagai pilihan pendidikan di Perguruan Tinggi. Hal tersebut terbukti dengan tingginya keinginan mahasiswa untuk mendalami ilmu Akuntansi, dan ketika mereka mendalami ilmu akuntansi ada perasaan senang saat mereka bisa menyelesaikan laporan keuangan yang menjadi salah satu tugas dari mata kuliahnya. Selain itu ketika mereka memilih program studi akuntansi ada harapan untuk mendapatkan gaji yang tinggi setelah lulus dan bekerja dalam bidang Akuntansi.

Pandangan mahasiswa program studi Akuntansi mengenai karir mereka saat bekerja nantinya setelah lulus bisa mereka kembangkan, salah satunya dengan bekerja di perusahaan. Kecenderungan mahasiswa untuk bekerja di perusahaan sangat tinggi yakni lebih dari 80\%. Ketika mahasiswa memilih program studi Akuntansi, mereka merasa memiliki peluang bekerja di perusahaan masih banyak karena profesi bidang Akuntansi juga beragam. Tingginya minat mahasiswa untuk bekerja di perusahaan selain karena peluang kerja yang dirasa masih banyak, juga karena mereka menganggap bahwa bekerja dalam bidang Akuntansi di perusahaan identik dengan pekerjaan kantor dengan suasana ruang kerja yang bersih dan nyaman.

\section{KESIMPULAN}

Berdasarkan pada hasil analisis data dan pembahasan dapat ditarik beberapa kesimpulan, antara lain: ada pengaruh secara simultan antara konformitas teman sebaya, motivasi, dan minat karir terhadap pemilihan program studi akuntansi di perguruan tinggi, ada pengaruh secara parsial konformitas teman sebaya terhadap pemilihan program studi akuntansi di perguruan tinggi, ada pengaruh secara parsial motivasi terhadap pemilihan program studi akuntansi di perguruan tinggi, dan ada pengaruh secara parsial minat karir terhadap pemilihan program studi akuntansi di 
perguruan tinggi. Konformitas teman sebaya, motivasi, dan minat karir berkontribusi sebesar 55,2\% terhadap pemilihan program studi akuntansi di perguruan tinggi

\section{DAFTAR PUSTAKA}

Aini, Yulfita. (2013). Pengaruh Motivasi internal, eksternal dan lingkungan kerja terhadap kinerja karyawan. Pengaraian: Univ. Pasir

Dalyono. (2005). Psikologi Pendidikan. Jakarta: Rineka Cipta

Djaali, H. (2008), Psikologi Pendidikan, Jakarta: Bumi Aksara

Djamarah, Syaiful Bahri (2008). Psikologi Belajar. Jakarta: Rineka Cipta.

Ester, Bowen (2013). Factors Influencing career choices of urban Agricultural Education students Geldard, David (2011) Konseling Remaja. Jakarta, Pustaka Belajar.

Irmawati, Basilia Ria (2008). Faktor yang mempengaruhi mahasiswa dalam memilih program studi di perguruan tinggi. Yogyakarta: Univ. Sanata Dharma.

Isnaeni, Rina (2015). Pengaruh motivasi, kelompok referensi dan biaya pendidikan terhadap keputusan mahasiswa dalam menempuh pendidikan pada jurusan pendidikan ekonomi fakultas ekonomi universitas negeri Yogyakarta.

Makhlufah (2013). Pengaruh Konformitas teman sebaya terhadap kepuasan memilih jurusan di madrasah aliah negeri (MAN) 2 pamekasan Madura. Univ. Islam negeri Maulana Malik Ibrahim

Myers, G D. (2012). Psikologi Sosial Buku 1. Edisi Kesepuluh. Jakarta: Salemba Humanika.

Priastuti, Dwi Pratiwi (2014). Hubungan konformitas teman sebaya dengan intensi pemilihan jurusan kuliah pada siswa kelas XI di SMAN 3 Malang. Malang: Univ. Brawijaya

Risnawati, Irwandi (2012) Analisis faktor atas pengambilan keputusan mahasiswa untuk memilih jurusan Akuntansi di STIE Perbanas Surabaya. Surabaya: STIE Perbanas

Rufaidah, Anna (2015). Pengaruh intelegensi dan minat siswa terhadap putusan pemilihan jurusan

Rumono, Henny Novita (2014). Hubungan intensitas komunikasi orang tua-anak dan kelompok referensi dengan minat memilih jurusan ilmu komunikasi pada siswa kelas XII. Semarang: Univ. Diponegoro.

Salulu (2008). Pengambilan keputusan strategik untuk organisasi publik dan organisasi nonprofit. Jakarta: PT.Gramedia Widiasarana Indonesia.

Santrock, John W. (2014). Psikologi Pendidikan (Buku 1) (Edisi 5). Jakarta: Salemba Humanika. Schunk, Dale H. (2012) Motivasi dalam Pendidikan, Teori, Penelitian dan Aplikasi. Jakarta, PT. Indeks. Simamora, Henry, (2001). Manajemen Sumber Daya Manusia. Penerbit STIE YKPN, Yogyakarta. Undang-undang RI No.20 Tahun 2003 tentang Sistem Pendidikan Nasional. (2004). Jakarta: PT Armas Duta Jaya. 